\title{
ISLANDS OF AFFLUENCE IN A SEA OF DESPAIR
}

I recently had the privilege of attending the Conference on Technology-Based Confidence Building: Energy \& Environment, hosted by Los Alamos National Laboratory and The University of California, in Santa Fe, New Mexico, July 9-14, 1989.

Natural scientists, political scientists, social scientists and writers were some of the 165 participants from 13 countries: Australia, Austria, Canada, China, Costa Rica, Germany, Israel, Italy, Japan, UK, US, USSR and Yugoslavia.

The "leit motif" of the conference quickly came into focus and that was to save our planet, earth, through aggressive measures in science, industry, politics and international cooperation. In our rapidly degenerating global environment, international security (ecological, that is, not military) is at stake. We are in a world of transition, moving away from the era of Cold War weapons production towards the current mood of "Perestroika" and the smoothing of bilateral relations. However we now face a far more fearsome foe-irreversible environmental degradation. What we most urgently need to defeat the deadly dragon is "metanoia," said Thomas Malone, St Joseph College Scholar in Residence, or a change in our thinking.

Intensive discussions on such issues as the Greenhouse Effect, acid rain, $\mathrm{CO}_{2}$ and methane levels, the ozone hole, deforestation, soil erosion, desiccation, alternative energy sources, chemical pollutants, population explosion and starvation led to recommendations from four specialized Workshops.

\section{ENVIRONMENTAL CHALLENGES}

\section{Chair: Will Kellogg, National Center for Atmospheric Research}

We must change our attitudes and perceptions; degradation of the carth is a present reality and remedial actions must be taken. The demand on natural resources by the population explosion must be carricd to the highest levels of government, economics and academia. The world is in transition from military to environmental security.

The public does not share the sense of urgency felt within the sciences and must be educated. Scientists have a special responsibility to inform, reach consensus and to translate findings into political action.

Third-world nations are not concerned with global change- their priorities put survival first. Global insults to the earth are largely due to the actions of $25 \%$ of the world population that controls $75 \%$ of the wealth, energy and resources. Wealthy nations are obligated to cooperate and advise the poor.

It is not likely that the world will switch from fossil fuels, but we must move away from these by investing in research and development, which will buy us time from inevitable warming. Our long-term view should be towards solar energy conversion, other renewable energy sources and safe nuclear reactors. We must take a hard look at the impacts of global warming in the next century and broadcast our findings to the international com- 
munity through a variety of governmental and non-governmental agencies.

\section{FISSION ENERGY}

Chair: Ron Augustson, Safeguards Assay Group, Los Alamos National Laboratory

Nuclear energy produces $17 \%$ of the world's electricity and is an acceptable cnergy option, given that we engage in a new generation of international projects towards nuclear reactor safety, nuclear waste disposal, safeguards (perhaps through the IAEA) and low-level radiation protection. Long-term energy alternatives should be sought, such as solar energy, fusion, conservation, cleaner fossil fuels, and a real commitment to the International Thermonuclear Experimental Reactor (ITER).

We must regain public confidence in nuclear energy through safe operation, communication and education. The re-establishment of nuclear energy should occur by the 21 st century. Although there should be no single monetary source for these technologies, expenses should be transferred in general from the military. Sociologists and psychologists should play a role in this global transition.

\section{CONSERVATION, FOSSIL FUELS AND RENEWABLES}

Chair: Robert Schock, Energy Program, Lawrence Livermore National Laboratory

An International Center for Research on knergy and Environment should be established. Its scope should include energy conversion and enduse efficiency, technological development and transfer, policy formulation, database maintenance, resource extraction, economic development of less developed countries and collaborative projects on global limits to carbon cmissions.

Dissemination of the results of this conference should be through the US National Academy of Sciences, the USSR Academy of Sciences as well as the legislative and executive branches of all national governments. A BushGorbachev "Environmental Summit" should be convened.

\section{EMERGENCY RESPONSE TO ACCIDENTS}

Chair: Ron Koopman, Lawrence Livermore National Laboratory

We must improve predictive capabilities for natural disasters, such as earthquakes, floods and tidal waves as well as for man-made disasters, such as radiation or chemical spills. An International Disaster Response Center should be established to coordinate programs for disaster response and the prevention and mitigation of accidents. The rarity of events make it difficult to maintain preparedness. Data bases should be maintained and pressure should be placed on the government to implement these measures.

Following the summaries of these dedicated scholars, organizer, Louis Rosen, of Los Alamos, closed the discussions on a note of optimism, liken- 
ing the scholars and their recommendations to "islands of affluence in a sea of despair."

I felt compelled to share this enriching and hopeful experience with my colleagues and call upon you, as scientists and citizens, to do what you can for the survival of the earth.

Renee Kra

Managing Editor 


\title{
The Mary Ingraham Bunting Institute of Radcliffe College
}

\section{Science Scholars Fellowship Program 1990-91}

\author{
Funded by the Office of Naval Research
}

As part of a $\$ 1.7$ million grant, the Bunting Institute will fund a total of 45 women scientists from 1989 to 1995. This grant represents the third consecutive renewal of support from the Office of Naval Research, which began its support of the Institute in 1980). Since that time, we have hosted 32 post-doctoral women scieritists and we will appoint seven new scholars for 199()-91.

\section{Eligibility}

Women scientists who are U.S. citizens or permanent residents are eligible for this program. Applicants must hold a Ph.D. degree by the date of appointment (July 1, 1990) in one of the following fields: astronomy, biochemistry, ecology, geology, physics, chemistry, engineering, computer science, mathematics, cognitive and neural science, and biological science.

Terms of Fellowship

$\$ 26,30)$ stipend plus research allowance for a one-year appointment, July 1, 199()-June 30, 1991. Private office space provided, along with access to Harvard/Radcliffe resources. Science Scholars are required to present a public lecture co-sponsored with the relevant Harvard University science department.

Residence Requirement

Science Scholars are required to be in residence in the Cambridge/Boston area for the entire term of appointment. We do not provide housing.

\section{Laboratory Affiliation}

If a laboratory affiliation is necessary to the proposed research project, applicants must establish an affiliation with a laboratory in the greater Boston area. It is not necessary to choose a laboratory at Hanard University.

Number of Fellowships Awarded for 1990-91

$$
\text { Seven. }
$$

Deadline

October 2, 1989 (postmurked). Applicants will be notified of their status by March 1990).

For Application Materials contact:

$$
\begin{gathered}
\text { Man Ingruham Bunting Institute } \\
\text { Rudcliffe College } \\
3+\text { Concord Avenue } \\
\text { Cambridge, MA } 02138 \\
(017)+95-8212
\end{gathered}
$$

